\title{
Um olhar sobre as autorizações de permanência a estrangeiros no Brasil, entre 2005 e $2011^{\star}$
}

\author{
Elaine Meire Vilela** \\ Daniela Portella Sampaio***
}

\begin{abstract}
A proposta geral desse artigo é apresentar uma análise descritiva dos estrangeiros autorizados a se estabelecer temporária ou permanentemente no Brasil, durante o período de 2005 a 2011, bem como sua relação com a política migratória brasileira. Para isso, foram utilizados os microdados da Coordenação Geral de Imigração (CNIg) do Ministério do Trabalho e Emprego. Considerando a literatura apresentada, o intuito é identificar se há uma tendência de seletividade dos estrangeiros autorizados a entrarem no país. Apesar de tal fato não poder ser testado, pois não se dispõe de informações sobre o perfil dos candidatos que tiveram seus pedidos de autorizações negados, é possível inferir sobre tal questão a partir dos dados analisados. Os resultados mostram que as autorizações concedidas são majoritariamente para trabalhadores profissionais e investidores, homens, altamente qualificados e de países, em geral, mais desenvolvidos (norte-americanos, europeus e asiáticos), com destino para o Sudeste. Esse perfil dos autorizados pode ser explicado, em parte, pela política migratória brasileira, que continua a ser restritiva e seletiva. Embora não se possa identificar a origem da seletividade - se o governo brasileiro, o mercado de trabalho (de origem e/ou de destino), ou as próprias solicitações dos estrangeiros -, verifica-se que a política migratória brasileira assegura tal seletividade, independentemente de quem venha a ser o agente dessa ação.
\end{abstract}

Palavras-chave: Estrangeiros. Política migratória. Autorizações. Seletividade.

\footnotetext{
* As autoras agradecem os comentários e as sugestões dos pareceristas da revista, importantíssimos para a melhoria do texto. Também, se faz um agradecimento à Fundação de Amparo à Pesquisa do Estado de Minas Gerais (Fapemig) pelo apoio financeiro ao projeto "Análise comparativa da inserção de imigrantes internacionais no mercado de trabalho na região Sudeste do Brasil, ao longo de 50 anos”, em que foi desenvolvido esse artigo.

** Departamento de Sociologia e Antropologia da Universidade Federal de Minas Gerais - UFMG, Belo Horizonte-MG, Brasil (emvilela@gmail.com, elainevilela@yahoo.com.br).

*** Instituto de Relações Internacionais da Universidade de São Paulo - USP, São Paulo-SP, Brasil (danirics@usp.br).
} 


\section{Introdução}

A partir da década de 1980, surgiu a hipótese de que o Brasil teria passado de um país de atração para um país de expulsão de pessoas (SALES, 1992). Entretanto, estudos empíricos demonstram que o Brasil continua a ser um local de absorção (em crescimento nos últimos anos) e de expulsão de pessoas (em queda, a partir de 2001, acentuando-se de 2008 em diante) (MARTES, 2009; BAENINGER, 2010; PATARRA; FERNANDES, 2011; FERNANDES; CASTRO; KNUP, 2012). As entradas de imigrantes no país continuam sendo significativas tanto quantitativa quanto qualitativamente (tratando-se das origens dos imigrantes) (SALES; SALLES, 2002).

De forma geral, o imigrante não é percebido como algo necessário e nem benéfico pela sociedade de destino, mas sim como desnecessário e oneroso, bem como indesejável e potencialmente perigoso (PÓVOA NETO, 2010). Isso explica, em parte, porque as políticas migratórias vêm, cada vez mais, aumentando o caráter restritivo. ${ }^{1}$ Assim, no Brasil, como em outros países, vem ocorrendo um aumento considerável no número de imigrantes clandestinos, dadas as dificuldades impostas à imigração regular (BONASSI, 2000; PATARRA; FERNANDES, 2011). Historicamente, o que se vê, a partir da política migratória brasileira, é uma seleção dos imigrantes qualificados - europeus e norte-americanos, principalmente - e uma grande restrição aos indivíduos com baixo nível educacional, originários de países pobres, em desenvolvimento (BARRETO, 2001; PATARRA, 2005).

No Brasil, muitos estudos buscam analisar diversas características do fenômeno da migração internacional no país. Alguns temas apresentam-se como centrais em diversas pesquisas, tais como a questão das relações de etnicidade (SEYFERTH, 1999, 2000; VILELA, 2002, 2011a; FíGOLI; VILELA, 2003), os conflitos étnicos (VILELA, 2002; KEHDY, 2010; FÍGOLI; VILELA, 2003), o processo de imigração (PATARRA, 1996, 2005; BAENINGER; PATARRA, 2006; BAENINGER, 2010, 2012; PATARRA; FERNANDES, 2011; SAKURAI, 1998, 2000) e a inserção no mercado de trabalho (SILVA, 1997, 2001; MELO; ARAÚJO; MARQUES, 2003; VILELA, 2011b; SOUCHAUD; CARMO; FUSCO, 2007; CAVALCANTI; OLIVEIRA; TONHATI, 2014). Outros assuntos são menos abordados, tais como a discriminação dos imigrantes no mercado de trabalho (VILELA, 2011b; SALA, 2005), as questões dos refugiados, das remessas e da fuga de cérebros do e para o país (MOULIN, 2011; PATARRA; FERNANDES, 2011; MARTES, 2009; BAENINGER; PERES, 2011).

Com intuito de contribuir com as pesquisas sobre imigração internacional e mercado de trabalho no Brasil, no sentido de trazer outras questões de debate e fontes de dados, procura-se analisar, neste artigo, os números, os tipos e as formas das autorizações con-

\footnotetext{
${ }^{1} 0$ caráter não desejável do imigrante que resulta em políticas migratórias restritivas por parte dos Estados receptores deve-se, muitas vezes, a aspectos conjunturais destas sociedades de destino. Problemas econômicos, crescimento da demanda por serviços públicos, ameaça figurada pelo terrorismo, disputas políticas domésticas e as consequências sociais negativas de uma não integração desses imigrantes (tais como discriminação social, racial e religiosa) são alguns dos inúmeros fatores que levam Estados a elaborarem políticas migratórias restritivas em resposta à chegada de grupos que desafiam o poder público.
} 
cedidas a estrangeiros para se estabelecerem, permanente ou temporariamente, ${ }^{2}$ no país, no período de 2005 a 2011. A proposta é identificar os números de autorizados a entrarem no país, as origens e características sociodemográficas desses indivíduos e as regiões e os estados de destino deles, além de analisar as situações de entrada no país, a partir do tipo de autorização/visto concedido, considerando a política migratória brasileira. Por meio dos microdados do Conselho Nacional de Imigração (CNIg), esse trabalho pretende complementar os estudos já feitos por Baeninger (2010), Fernandes, Castro e Knup (2012), e Cavalcanti, Oliveira e Tonhati (2014), permitindo assim uma compreensão mais detalhada do perfil e da situação dos grupos autorizados a entrarem no Brasil.

Vale ressaltar que esse trabalho não pretende discutir e explicar os movimentos migratórios, que podem ser compreendidos pelas diversas teorias fundamentadas nas abordagens micro (perspectiva individual e/ou familiar) e/ou macro (perspectiva histórico-estrutural) existentes. Um olhar para tais teorias, como, por exemplo, a neoclássica, a do mercado dual, a histórico-estrutural, a transnacional, a de redes, a do sistema mundial, entre outras, ajuda a compreendermos o cenário migratório atual (PIORE, 1979; PORTES, 1995; MASSEY et al., 1993). Entretanto, isso não é exposto nesse estudo, pois o objetivo não é entender porque as pessoas migram (obtenção de trabalho, diferenças econômicas regionais, reunião familiar, refúgio, asilo, entre outros fatores) e nem identificar de quem foi a decisão de migrar (se individual, familiar ou de algum grupo maior). A meta é entender melhor o perfil dos estrangeiros autorizados a permanecerem no país e o tipo de inserção, considerando a política migratória vigente no Brasil e pensando a respeito de uma seletividade existente ou não na concessão de autorização para estabelecimento no país.

\section{As políticas migratórias brasileiras: visão geral}

A dimensão política é um dos instrumentos mais importantes de controle de incidência de migração, podendo dificultar ou facilitar os deslocamentos humanos no Estado (PÓVOA NETO, 2010). Historicamente, em geral, a política migratória brasileira foi restritiva. A despeito de uma visão popular do Brasil como um país aberto à imigração, hospitaleiro, um território de oportunidades, constata-se que os bastidores guardam a memória de um país racista, intolerante e fechado às diferenças étnicas e políticas (CARNEIRO, 2003, p. 258). Como exemplos, temos: a Constituição de 1934, que adotou o regime de cotas, em que estabelecia, para cada origem, um máximo de $2 \%$ sobre o número total dos respectivos nacionais residentes no país, durante os 50 anos anteriores à referida data; "ainda em 1934, outras medidas adotadas impediram a entrada no Brasil de imigrantes analfabetos" (TRUZZI, 2003, p. 245); também, em 1937, uma circular expedida pelo Itamaraty estabelecia a proibição à concessão de vistos para indivíduos de origem semítica (CARNEIRO, 2003).

\footnotetext{
${ }^{2}$ Vale destacar que, em alguns casos, a definição estrita de migração não pode ser usada, já que não há uma mudança definitiva, ainda que temporária, de endereço, como é o caso, por exemplo, dos trabalhadores em embarcações de turismo.
} 
Outro exemplo, mais atual, é a Resolução Normativa n. 97 de 12/01/2012, que estabelecia cota para haitianos no Brasil (BRASIL, 2012).

Com o crescimento da imigração internacional no último século, uma interpretação mais liberal da Declaração dos Direitos Humanos tentava garantir a proteção dos imigrantes nos Estados receptores e o seu direito à reunificação familiar (REIS, 2004). Assim, diante da controvérsia, a Organização Internacional do Trabalho (OIT) estabeleceu a Convenção de Imigração do Trabalho (n. 97, 1949) e a Convenção dos Trabalhadores Imigrantes (n. 143, 1975), na tentativa de garantir que os imigrantes recebessem o mesmo tratamento destinado aos cidadãos de seus destinos.

Entretanto, essa orientação não foi internalizada plenamente pelos Estados membros, inclusive no Brasil (CARNEIRO, 2003). Ainda hoje existe uma política migratória que dificulta em muito a entrada de imigrantes internacionais no território brasileiro. Essa baseia-se no Estatuto do Estrangeiro, Lei n. 6.815 de 19 de agosto de 1980. Há várias críticas a essa lei, principalmente por estar fundamentada no caráter autoritário da época em que foi estabelecida (período militar) e na preocupação com a defesa nacional e por não considerar os tratados internacionais, bem como os direitos fundamentais da pessoa humana (BONASSI, 2000; PATARRA, 2005; BRASIL, 2010). Entretanto, alguns avanços, ainda que não satisfatórios, podem ser identificados, ao longo do tempo, pautados em uma ótica dos direitos humanos. Um exemplo refere-se à constituição dos representantes do Conselho Nacional de Imigração (CNIg). Há representação dos diversos ministérios do governo federal, da sociedade civil (tais como trabalhadores, empregadores e organizações não governamentais) e das instituições de ciência e tecnologia. ${ }^{3}$ Essa representação de diversas instituições é um fator extremamente positivo para o conselho, uma vez que várias visões são levadas em consideração ao se discutir qualquer assunto relacionado ao tema da migração.

Dessa forma, esse conselho torna-se um órgão importantíssimo para os avanços das políticas migratórias. Destaca-se o fato de que, em 2009, o CNIg enviou uma nova proposta de lei de migração (Projeto de Lei n. 5.655/2009)4 ao Congresso Nacional, a qual determina que "a política nacional de migração contemple a adoção de medidas para regular os fluxos migratórios de forma a proteger os direitos humanos dos migrantes, especialmente em razão de práticas abusivas advindas da situação migratória irregular” (BRASIL, 2010, p. 52).

Avanço na política migratória pode ser visto também nas mudanças de resoluções no que diz respeito às autorizações de trabalho propostas pelo CNIg, como, por exemplo, das Resoluções Normativas n. 84/2009, que facilita a obtenção de visto permanente para pequenos empregadores do Cone Sul, e n. 80/2008, que retira obstáculos para obtenção de visto pelos cidadãos sul-americanos no Brasil (BRASIL, 2010).

\footnotetext{
${ }^{3}$ Para mais detalhes, ver Brasil (2010).

${ }^{4}$ Vale destacar que já há um novo Projeto de Lei (PL n. 206/2011) como forma do substituto do PL n. 5.655/2009. Link para o acompanhamento da tramitação do Projeto de Lei no Congresso (outubro de 2011): 〈http://www.camara.gov.br/ proposicoesWeb/fichadetramitacao?idProposicao $=443102$ >.
} 
Outro progresso observável na política oficial refere-se ao estabelecimento da Lei n. 9.474/97, que expande a definição de refugiados ao incluir, sem reservas, ${ }^{5}$

pessoas perseguidas por motivos de raça, nacionalidade, religião, grupo social ou opiniões políticas. Como inovação, a lei brasileira também considera refugiado o indivíduo que, devido à grave e generalizada violação de direitos humanos, é obrigado a deixar seu país de nacionalidade e buscar refúgio em outro país (BARRETO, 2003, p. 207).

Vale ressaltar que, em 1960, o Brasil foi o primeiro país na América do Sul a ratificar a convenção de 1951, ${ }^{6}$ referente ao Estatuto dos Refugiados e, em 1997, a sancionar a Lei de Refúgio. Em 1998, o país criou o Comitê Nacional para os Refugiados (Conare), que tem a finalidade de conduzir a política nacional sobre os refugiados (BARRETO, 2003).

Além da inclusão da questão dos refugiados, são observados progressos na política oficial também na busca por soluções para o problema dos imigrantes irregulares no país, como, por exemplo, os quatro processos de anistia ${ }^{7}$ implementados no país em 1980, 1988, 1998 e 2009. Representantes do centro de estudos migratórios de São Paulo ${ }^{8}$ e da pastoral do migrante afirmam que foi baixa a porcentagem de imigrantes que se beneficiaram com a lei da anistia (BONASSI, 2000; SALES; SALLES, 2002).

Vale chamar atenção também para o caso dos acordos bilaterais de regularização migratória para livre residência feitos entre Brasil e países do Mercosul. No caso específico dos bolivianos, foi assinado um acordo entre Brasil e Bolívia em 15 de agosto de 2005, com prorrogação até 14 de setembro de 2007. Uma nova prorrogação do referido acordo foi feita para um período adicional de um ano, a partir de 15 de setembro de 2007 (PÓVOA NETO; SPRANDEL, 2009).

\section{A regulação da migração no país e a questão da seletividade dos imigrantes}

No Brasil, as principais restrições para a entrada de imigrantes internacionais no país não se encontram no Estatuto do Estrangeiro, mas sim nos trâmites para obtenção do visto de residência temporária ou permanente (BONASSI, 2000).

Ao Ministério do Trabalho e Emprego cabe a concessão de visto temporário ou permanente ao estrangeiro, além de lhe dar assistência jurídica em questões de direito de família, de detentos e de situações de risco. Os vistos temporários são os mais outorgados, sendo

\footnotetext{
${ }^{5}$ Segundo Bonassi (2000), o país, manteve a cláusula da "reserva geográfica" em seu Estatuto do Refugiado até 1989, aceitando apenas refugiados originários do continente europeu. Assim, refugiados latino-americanos não tinham amparo no Brasil.

${ }^{6}$ Em Genebra, em 28 de julho de 1951, foi redigida uma convenção regulatória do status legal dos refugiados, a qual entrou em vigor apenas em 1954, apresentando os direitos dos refugiados. Essa convenção deve ser aplicada sem discriminação de raça, religião, sexo e país de origem. Além disso, ela estabelece a cláusula do princípio de não devolução, isto é, nenhum país deve expulsar ou "devolver" um refugiado, contra a vontade do mesmo, para um território onde o referido sofra perseguição. Para mais informações, ver no site da ACNUR em: 〈http://www.acnur.org/t3/portugues/informacaogeral/o-que-e-a-convencao-de-1951/>.

${ }^{7}$ Embora sejam muitas as críticas feitas a essas tentativas, as mesmas são vistas como avanços.

8 Esse centro foi constituído em 1969 pelos missionários escalabrinianos em São Carlos, com o objetivo de ajudar na inserção do imigrante na sociedade hospedeira. Para mais informações, ver o site 〈www.cemsp.com.br〉.
} 
concedidos àqueles que pretendem vir ao Brasil em viagem cultural (prazo de permanência de acordo com a duração da missão) ou de negócios (prazo de 90 dias), na condição de artista ou desportista (90 dias), na condição de estudante, cientista, professor, técnico ou profissional (sob regime de contrato ou serviço do governo brasileiro), na condição de correspondente de jornal, revista, rádio, televisão, agência de notícia estrangeira (até a duração da missão), e na condição de ministro de confissão religiosa ou membro de uma ordem religiosa (prazo de um ano) (BRASIL, 1981a).

0 visto permanente é concedido àqueles que pretendem se fixar definitivamente no Brasil e, segundo o artigo $16^{\circ}$, Parágrafo Único, da Lei n. 6.815/80, essa concessão deve ser orientada para uma imigração que objetiva "propiciar a mão-de-obra especializada aos vários setores da economia nacional, visando ao aumento da produtividade, à assimilação de tecnologia e à captação de recursos para setores específicos" "(BRASIL, 1981b). Assim, o imigrante deve satisfazer as exigências previstas nas normas de seleção de estrangeiros, ${ }^{10}$ estabelecidas pelo CNIg, cabendo a este toda a normatização quanto aos critérios específicos de obtenção de vistos temporários e permanentes, o que é feito por meio de resoluções normativas.

De maneira geral, pode-se observar que os critérios predominantes para concessão de visto aos estrangeiros são profissionais ${ }^{11}$ (priorizando a vinda de técnicos, pesquisadores, estudantes, gestores e investidores) (BONASSI, 2000; FERNANDES; CASTRO; KNUP, 2012). Estar essa concessão a cargo do Ministério do Trabalho e Emprego pode elucidar o maior peso das resoluções para o caráter profissional, atendendo a demandas e necessidades do mercado de trabalho.

Apesar de o Estatuto do Estrangeiro (1980) ser a linha base de orientação para a normatização das autorizações de permanência no país, muitas circunstâncias não conseguem ser abrangidas por ele, de modo que o uso de resoluções normativas é feito intensamente, principalmente a partir do fim da década de 1990 e correntemente ao longo dos anos 2000 (BAENINGER, 2010). Outro ponto que permanece subjacente às análises do caráter das concessões de permanência no Brasil é a preferência com base nos grupos étnicos e nacionais. Embora a questão étnica/nacional não seja explicitada na lei, estudos anteriores mostram que historicamente há grupos étnico/nacionais desejáveis para a entrada no Brasil e outros tidos como indesejáveis (ARAÚJ0, 2000; BONASSI, 2000; AZEVEDO, 2012). A preferência por um grupo e não por outro pode estar associada a diversos critérios de seletividade, tais como hábitos culturais, opção religiosa, cor/raça, ou seja, em uma discriminação pura, baseada em ideologias.

\footnotetext{
${ }^{9}$ Vale lembrar que a concessão de visto permanente, muitas vezes, está condicionada ao exercício de atividade certa e à fixação em região determinada no território nacional, por prazo não superior a cinco anos (BRASIL, 1981a).

${ }^{10}$ As exigências especiais previstas nas normas de seleção de imigrantes não se aplicam aos portugueses.

${ }^{11}$ Essa priorização no trabalhador e, em específico, no profissional não é diferente do que é praticado por outros países característicos de maior fluxo de imigrantes, como Estados Unidos, Canadá, Austrália, Alemanha, entre outros.
} 
Um fator importante que impacta na definição dos grupos de imigrantes desejáveis ou indesejáveis refere-se aos períodos de crises ou guerras. Exemplo clássico no Brasil ocorreu no final do século XIX e início do XX, quando eram os europeus (italianos, portugueses, espanhóis e alemães principalmente) os estrangeiros desejáveis, enquanto japoneses e chineses (principalmente) e "árabes"12 eram os indesejáveis. Com a Primeira Guerra Mundial, os membros de grupos nacionais inimigos deixaram de ser bem-vindos ao país, como no caso de alemães e italianos. Já com a Segunda Guerra, os japoneses, que já não eram bem quistos, passaram a sofrer maiores pressões para não entrarem no país e, entre os que já residiam no Brasil, a coerção era grande para que deixassem o território (KEHDY, 2010).

Outro critério de seletividade dos estrangeiros encontra-se na relação de poder econômico entre Estados-nações. Isto é, imigrantes oriundos de países pouco desenvolvidos podem não ser bem recebidos no país, encontrando assim obstáculos na entrada no território brasileiro (VAINER, 2001). Por fim, há evidências de uma seletividade no que diz respeito à qualificação do trabalhador migrante e ao seu nível educacional. Em fins do século XIX e início do XX, os agricultores, em maior número, e os artesãos eram os trabalhadores desejáveis para entrarem no país. Atualmente, há interesse em facilitar a vinda de profissionais de alto nível - cientistas, pesquisadores, professores e técnicos de alto nível - e em dificultar a inserção de trabalhadores sem qualificação ou semiqualificados (SALES; SALLES, 2002; FERNANDES; CASTRO; KNUP, 2012). ${ }^{13}$

A partir do exposto, dada uma política historicamente restritiva imposta no Brasil, conjectura-se que pode ainda haver uma tendência de seletividade dos estrangeiros autorizados a entrarem no país para trabalho, sendo que essa seletividade tem a ver, principalmente, com a qualificação (capital humano) dos solicitantes e com o país de origem dos mesmos (se país desenvolvido ou em desenvolvimento).

\section{Metodologia}

Para a realização da pesquisa, utilizou-se como fonte de dados o levantamento de registros administrativos do CNIg do Ministério do Trabalho e Emprego de 2005 a 2011 (CNIG, 2012), concedidos por este órgão para fins exclusivos de análise estatística. A base contém um total de 294.220 autorizações temporárias e permanentes para a estadia de estrangeiros no país, ou seja, microdados com referência a indivíduos que foram autorizados a permanecer por um período determinado no país (podendo ter esta renovação autorizada ou não); ou que obtiveram uma autorização definitiva de estadia.

Importante destacar que esses dados permitem obter informação apenas de entrada dos estrangeiros, mas não de sua saída do país (ou seja, com relação ao fim de sua autorização). Portanto, não é possível calcular os fluxos referentes à contabilização de entradas

\footnotetext{
$\overline{12}$ Incluindo, basicamente, sírios e libaneses.

${ }^{13}$ Vale destacar que isso é válido, principalmente, para o que chamamos de imigração econômica, o que pode não ocorrer para os casos dos estrangeiros que demandam entrada no país como reunificação familiar, refugiado ou ajuda humanitária.
} 
e saídas para o período. No entanto, essa fonte de dados contribui para a compreensão do perfil dos estrangeiros e, principalmente, das funções que eles possam vir a desempenhar no mercado de trabalho brasileiro, dado que as autorizações de trabalho representam a maioria dos casos.

A base de dados não sofreu alterações, pois a presente análise é apenas de caráter descritivo. Assim, as variáveis que estruturam o banco e que foram utilizadas para análise do perfil do grupo são: sexo, idade, nacionalidade, escolaridade, país de origem, unidade federativa de destino, tipo de estadia no país (se a autorização é por prazo determinado ou definitivo) e tipo de autorização concedida ao indivíduo para entrada no Brasil de 2005 a 2011, ou seja, a ocupação profissional estabelecida para a atuação do estrangeiro no país; ou, simplesmente, a justificativa que embasa a permissão de sua presença no país. ${ }^{14}$

Chama-se a atenção para o fato de ser essa a única fonte de dados que apresenta de maneira precisa o número oficial de entrada de estrangeiros no país e em que situação eles estão entrando no território, isto é, para trabalho, estudo, reunificação familiar, refugiados, ajuda humanitária, entre outros. Entretanto, da mesma forma que em outras fontes de dados, notam-se algumas limitações já identificadas por outros trabalhos (BAENINGER, 2010; BRASIL, 2010; FERNANDES; CASTRO; KNUP, 2012), tais como: inexistência de informação precisa sobre a duração da permanência desse estrangeiro no país; impossibilidade de verificar a complexidade dos fluxos migratórios, já que há apenas o conhecimento da nacionalidade do estrangeiro e não do país de residência anterior; e exclusão dos imigrantes indocumentados nesta análise. Contudo, ao prover uma análise de entrada e do tipo de autorização concedida ao indivíduo, essa fonte contribui com uma perspectiva diferenciada sobre a configuração atual da migração autorizada no Brasil.

\section{Número, origens e destinos}

No período analisado há um considerável aumento no número geral de autorizações, ou seja, autorizações tanto temporárias quanto permanentes que são concedidas para a entrada de estrangeiros no país, que passaram de 3.792, em 1995, para mais de 70.000, em 2011 (Gráfico 1). Os maiores picos ocorreram em 1998, 2008 e 2011. Essa elevação confirma o caráter do Brasil como destino nos últimos anos.

Esse crescimento pode ser compreendido pelo fato de que a mobilidade humana tornou-se protagonista no cenário internacional atual. Segundo Castels e Miller (1993), vivemos na era da migração. Outro fator que ajuda a entender essa elevação nos números, principalmente após 2007, encontra-se na crise enfrentada pelos países desenvolvidos (característicos de absorção de imigrantes) de forma mais forte e no crescimento

\footnotetext{
${ }^{14}$ Ressalta-se que os dados concedidos pelo CNIg contêm outras informações além destas, quais sejam: mês e ano de autorização, data de entrada, data de nascimento, tipo de amparo legal, CBO (Classificação Brasileira de Ocupação), CNAE (Classificação Nacional de Ramo de atividade), número de dependentes, número do processo e número do passaporte.
} 
econômico e social, ainda que bastante modesto, vivenciado pelo Brasil (CAVALCANTI; OLIVEIRA; TONHATI, 2014).

GRÁFICO 1

Número de autorizações temporárias e permanentes para estadia no país concedidas a estrangeiros Brasil - 1993-2011

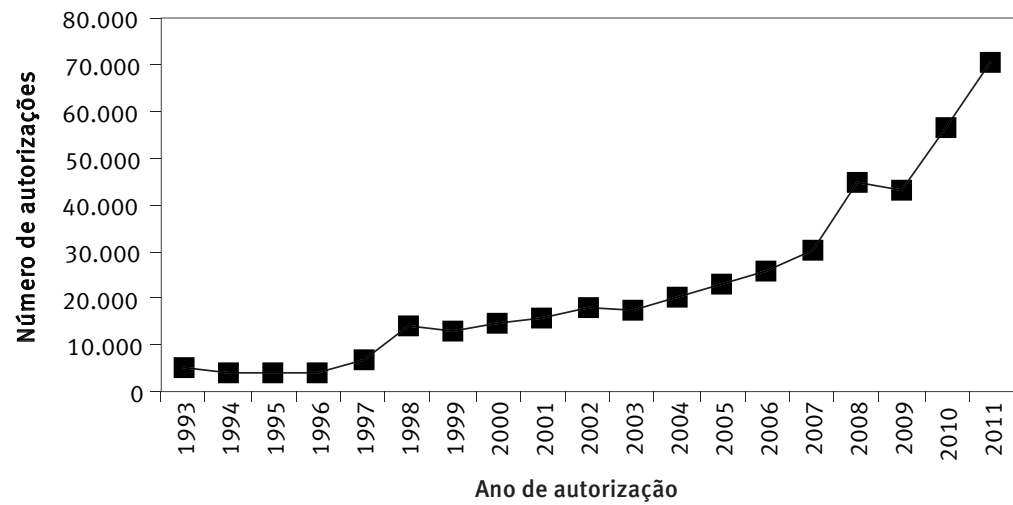

Fonte: Brasil (2010); microdados do Conselho Nacional de Imigração (CNIG, 2012).

Analisando o total de autorizações concedidas entre 2005 e 2011, verifica-se uma variação segundo o tempo de permanência do estrangeiro no Brasil, ou seja, estadia permanente ou temporária. Dos 294.215 casos válidos, 94\% (276.466) correspondem a concessões de caráter temporário no país, restando apenas 6\% (17.749) de autorizações para residência permanente e ambos os tipos apresentam estabilidade nestes valores entre 2005 e 2011. Esse panorama era esperado, já que, como exposto em estudos anteriores (SAYAD, 1998; SIQUEIRA, 2009), o imigrante, majoritariamente trabalhador, tem a pretensão de uma residência temporária no destino, tempo suficiente para obter algum dinheiro e retornar à origem; além, é claro, da migração transnacional que vem se intensificando nos últimos anos (CASTELS; MILLER, 1993). Já no caso de obter sucesso financeiro, encontrar um ambiente receptivo na sociedade e reunir sua família, é provável que o imigrante busque por um estabelecimento permanente (PORTES, 1995).

Para uma melhor configuração do retrato deste contingente de estrangeiros, é importante também observar a origem dos autorizados a permanecerem no Brasil. 0 Gráfico 2 apresenta os principais países de origem dessas pessoas: Estados Unidos, Filipinas, Grã-Bretanha, Índia, Alemanha, China, França, Itália, Japão, Noruega, Indonésia, Espanha, Canadá, Holanda, Portugal, Colômbia, Polônia, Argentina e México (em ordem decrescente). Estes representam um percentual cumulativo próximo de $52 \%$, para todos os anos. Observa-se crescimento do número de autorizações ao longo dos anos para esses grupos, com exceção da Argentina (que registra uma ligeira queda). De maneira geral, a maior parte das autorizações concedidas é para indivíduos de origens europeia, norte-americana e asiática.

Entre os países da América do Sul, são os indivíduos oriundos da Argentina que se destacam, seguidos pelos colombianos. Vale ressaltar que os bolivianos não chegam a 
representar nem $1 \%$ do total de estrangeiros com permissão para se inserir no país, nos anos analisados. Esse resultado é bastante curioso por dois motivos: em 2009, o governo concedeu anistia aos imigrantes ilegais no país, com perspectiva de atingir, majoritariamente, os bolivianos; ${ }^{15}$ e estudos demonstram que, no período analisado, aumentou significativamente o número de bolivianos imigrados para o Brasil (BAENINGER, 2012). Isso sugere que tais imigrantes estão entrando no país de forma clandestina. Dessa forma, é possível pensar em uma seletividade negativa quanto às autorizações concedidas a esse grupo. Mas isso é algo a ser discutido em outro estudo, uma vez que os dados dessa pesquisa não são suficientes para evidenciar tal seletividade.

Chama-se a atenção aqui para o percentual alto de filipinos e indianos entrando no país, no período analisado. Esse dado é interessante e leva a pensar na necessidade de estudos que apresentem esses grupos étnicos/nacionais como objeto de análise no país. As autorizações concedidas a esses estrangeiros são para trabalhos bastante temporários, tais como funcionários de embarcações marítimas de turismo e/ou pesca. Portanto, a estadia no país seria bem curta, provavelmente não acarretando em residência fixa em sua maioria.

\section{GRÁFICO 2}

Evolução do número de autorizações temporárias e permanentes para estadia no país concedidas a estrangeiros, segundo país de origem

Brasil - 2005-2011

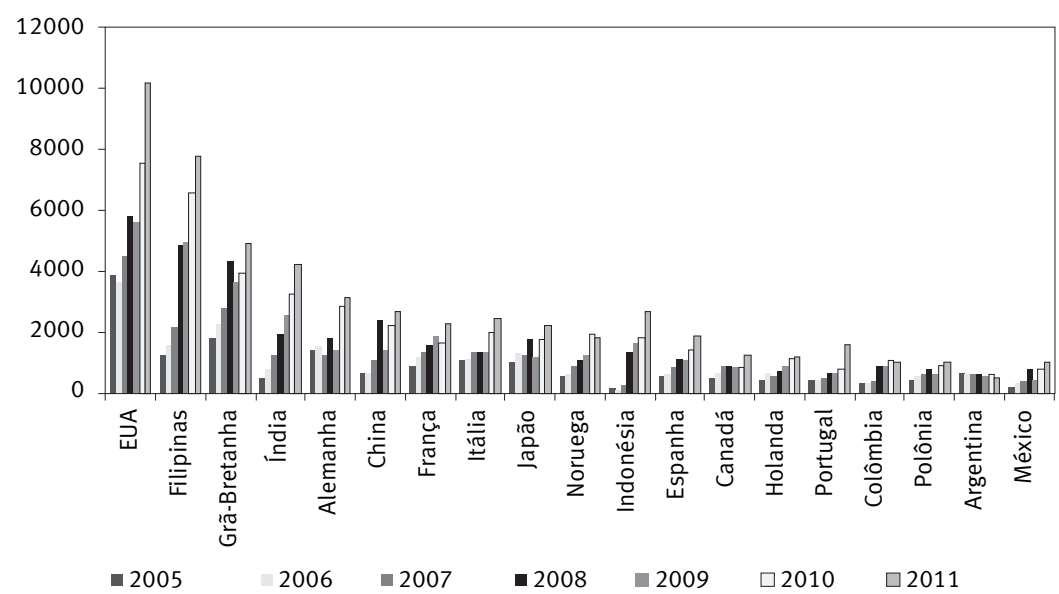

Fonte: Microdados do Conselho Nacional de Imigração (CNIG, 2012); Ministério do Trabalho e Emprego.

0 destino principal dos imigrantes autorizados concentra-se, fundamentalmente, na Região Sudeste. De 2005 até 2010, houve um aumento do percentual de entrada para essa região (de $86,6 \%$ para $91,9 \%$ ) e uma queda no Nordeste (de $4,6 \%$ para $2,4 \%$ ). Entre 2010 e 2011, o padrão se inverteu, com redução para a primeira (passando para $88,2 \%$ )

\footnotetext{
15 o que os dados sugerem é que essa ação não foi muito eficiente, já que, em 2009, apenas 118 autorizações foram concedidas para tal grupo, contra 169 em 2008, 104, em 2007, 76 em 2006 e 68 em 2005. Posteriormente, o número de autorizações continuou baixo, com 90 em 2010 e 79 em 2011.
} 
e acréscimo na segunda região (chegando a 4,8\%). No Gráfico 3, podem ser observados os principais estados de destino dos imigrantes: São Paulo, Rio de Janeiro (sendo que somente os dois reúnem o percentual cumulativo de mais de $80 \%$ dos imigrantes autorizados), seguidos por Minas Gerais, Amazonas e Paraná. Os estados do Nordeste também possuem uma participação relativamente significativa (Rio Grande do Norte, Ceará, Bahia e Pernambuco), configurando-se, ao fim, como a segunda região de destino para os estrangeiros inseridos no país, à frente inclusive do Sul. De 2005 a 2007, o Rio de Janeiro apresentou um percentual maior de destino dos autorizados do que São Paulo. Esse quadro se inverteu em 2008, retornou em 2009, mas reverteu-se em 2010 e 2011.

GRÁFICO 3

Número de autorizações temporárias e permanentes para estadia no país concedidas a imigrantes, segundo principais Unidades da Federação

Brasil - 2005-2011

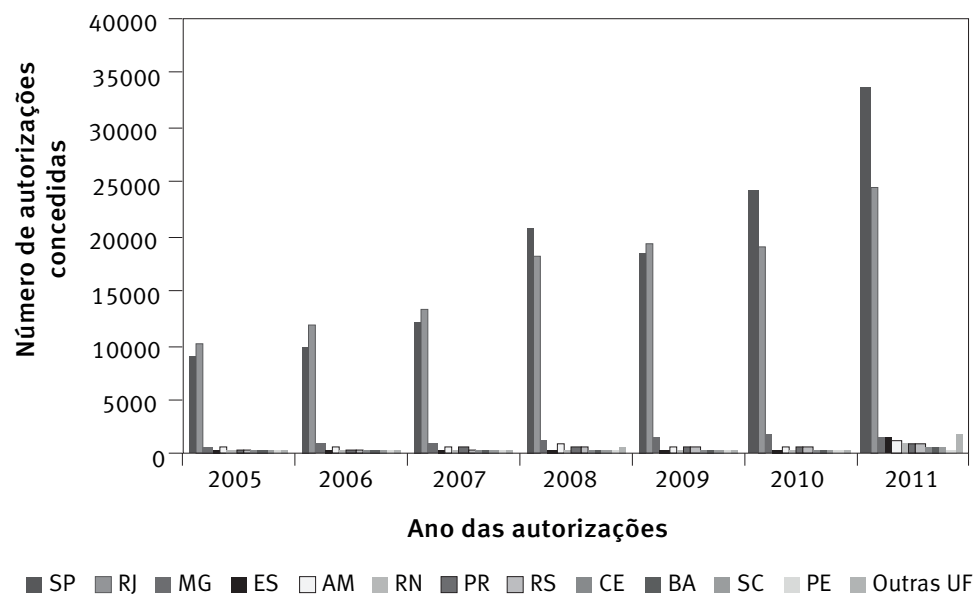

Fonte: Microdados do Conselho Nacional de Imigração (CNIG, 2012); Ministério do Trabalho e Emprego.

\section{Quem são esses estrangeiros?}

Esta última seção dedica-se à análise do perfil sociodemográfico de todos os estrangeiros autorizados a se estabelecerem no país de forma temporária ou permanente entre 2005 e 2011 e, também, da situação deles com relação ao tipo de autorização recebida, o que revela, ainda que de forma indireta, a situação dos mesmos no mercado de trabalho brasileiro.

É notável que a quase totalidade de autorizações é destinada aos homens, que representam 90,6\% (266.706) de todas as autorizações do período analisado, enquanto as mulheres correspondem a somente 9,4\% (27.514), já incluindo, inclusive, aquelas que acompanham seus cônjuges sob a autorização normativa de reunificação familiar. Esse quadro mantém-se relativamente constante ao longo dos anos em estudo e é semelhante 
para aqueles com visto tanto permanente quanto temporário. Esse resultado vai contra a teoria da feminização da imigração, exposta por alguns autores (CASTELS; MILLER, 1993). Isso indica uma seletividade devida a questões de gênero e, portanto, um tema que deve estar na agenda de pesquisa futura.

Com relação ao nível educacional, de acordo com os dados, das 294.220 autorizações no período analisado, $60,4 \%$ foram concedidas para indivíduos que possuem ensino superior completo ou mais, enquanto $39,3 \%$ correspondem a pessoas com ensino médio ou superior incompleto, o que caracteriza uma alta escolaridade do grupo. Ao se comparar o nível educacional de estrangeiros com vistos permanentes ou temporários no país, o percentual é um pouco diferente. Entre os primeiros, $69 \%$ possuem nível superior ou mais, contra $57 \%$ para os estrangeiros do segundo grupo. Quando o nível educacional é analisado por ano de autorização do período, observa-se certa constância nos valores, o que leva a uma caracterização definitiva do grupo de estrangeiros como de alta escolaridade.

Esse panorama pode também ser um indício de seletividade quanto ao capital humano (mensurado pelo nível educacional) dos autorizados. ${ }^{16}$ Os não qualificados continuam entrando pelas portas dos fundos, como já evidenciado por outros estudos (BONASSI, 2000; MARTES, 2009; BAENINGER, 2012). ${ }^{17}$ Conforme exposto anteriormente, o Estatuto do Estrangeiro especifica que o interesse é de assegurar uma imigração que, primordialmente, propiciará “mão-de-obra especializada aos vários setores da economia nacional, visando à Política Nacional de Desenvolvimento em todos os aspectos e, em especial, ao aumento da produtividade, à assimilação de tecnologia e à captação de recursos para setores específicos" (BRASIL, 1981c, art. 16).

Os estrangeiros, quando analisados segundo a faixa etária, mostram-se na etapa da vida adulta, em geral. A média de idade observada nos dados cumulativos é de 38,24 anos, com um desvio-padrão total de 10,6 anos. Ao longo do período analisado, não houve uma significativa variação na média de idade do grupo, o que leva a uma configuração mais permanente desta característica.

A situação dos indivíduos autorizados a entrarem no Brasil pode ser bastante elucidada por meio da análise dos tipos de autorizações concedidas a eles. A frequência das autorizações é distribuída pelas modalidades existentes, principalmente por meio das resoluções normativas, que acabam por servir de ferramenta para formalizar a estada e a atividade ocupacional dos grupos que o país tem interesse em atrair para o mercado nacional.

É possível perceber os tipos de autorizações temporárias e permanentes mais frequentes definindo o perfil das atividades realizadas pelos estrangeiros. As que tiveram representações significativas para os anos analisados são: transferência de tecnologia e/

\footnotetext{
${ }^{16}$ Vale lembrar que o nível educacional da população em todos os países vem aumentando cada vez mais (COLINS, 1979) e isso afeta o perfil do migrante que, em geral, já é mais educado, como exposto pela teoria da seletividade positiva do migrante (CHISWICK; 1999, VILELA, 2011).

${ }^{17}$ Outro ponto a considerar é que a seletividade, baseada no capital humano, é característica de uma migração econômica (o estrangeiro que vem para trabalhar) e não para uma migração de reunificação familiar, ou de refugiados e ajuda humanitária (como é o caso de haitianos entrando no Brasil).
} 
ou prestação de serviço de assistência técnica sem vínculo empregatício; profissionais, tripulantes e técnicos estrangeiros para trabalho a bordo de embarcação ou plataforma estrangeira sob contrato de prestação de serviços e de risco; marítimos estrangeiros em embarcação marítima de turismo estrangeira; artistas ou desportistas sem vínculo empregatício; empregados com contrato de trabalho; administradores, diretores, gerentes e executivos; e vistos permanentes para investidor estrangeiro/pessoa física.

Analisando os tipos de autorizações concedidas de 2005 a 2011 (Gráfico 4), observa-se, em geral, uma pequena instabilidade entre os diversos tipos (crescimento e queda, ainda que pequena), com exceção do aumento constante e relevante ao longo do período analisado da autorização para trabalho a bordo de embarcações de prestação de serviço de risco. Uma explicação para isso encontra-se na demanda do Brasil por tais profissionais, dada a exploração de petróleo e o pré-sal. Chama-se a atenção também para o caso dos marítimos de embarcações de turismo, cujas autorizações vêm crescendo nos últimos anos, em função do aumento dos cruzeiros marítimos em rotas brasileiras.

\section{GRÁFICO 4}

Evolução do número de autorizações temporárias e permanentes para estadia concedidas para imigrantes, segundo tipo de trabalho

Brasil - 2005-2011

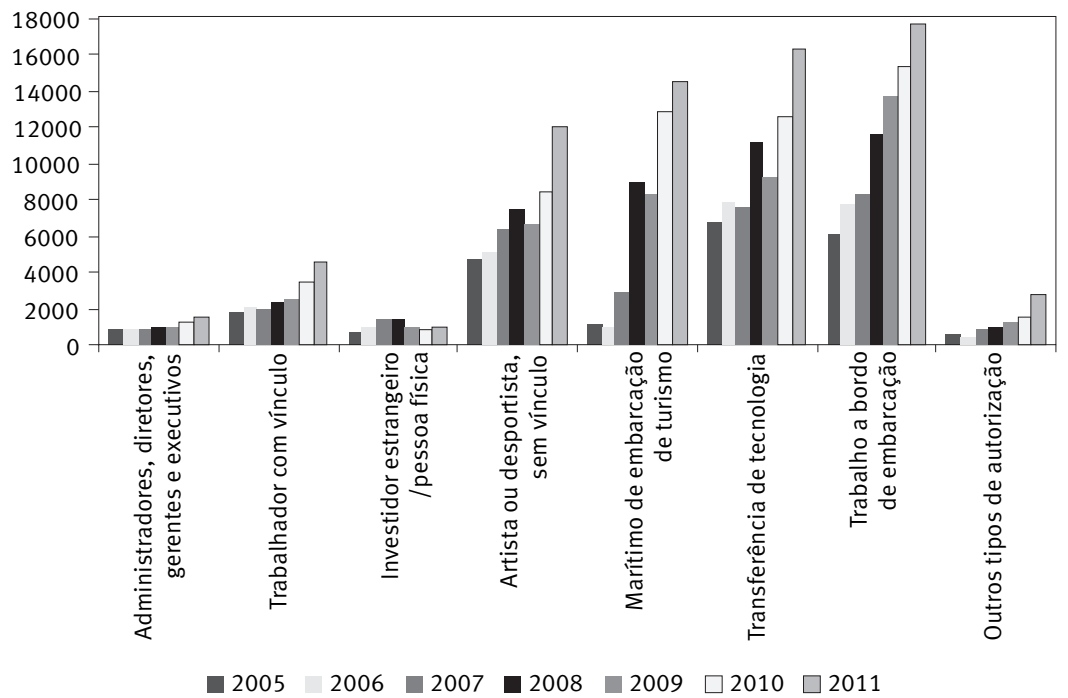

Fonte: Microdados do Conselho Nacional de Imigração (CNIG, 2012); Ministério do Trabalho e Emprego.

Um estudo da Fundação Getúlio Vargas (FGV, 2012) mostrou que, desde a temporada $2004 / 2005$, houve um aumento considerável do fluxo de cruzeiros marítimos na costa brasileira. Elevou-se não só a quantidade de navios, como também as rotas no país. Atualmente, os EUA despontam como o principal fornecedor de cruzeiros, seguidos por Inglaterra, Alemanha, Itália e, agora, o Brasil em quinto lugar (FGV, 2012). Vale destacar o fato de Rio de Janeiro e Santos serem os principais portos de embarque e desembarque desses tran- 
satlânticos, o que ajuda a explicar o percentual altíssimo de estrangeiros concentrados nos Estados de São Paulo e Rio de Janeiro, como exposto anteriormente. Ressalta-se que São Paulo representa o principal porto de entrada desses navios, uma vez que, considerando os dados de todos os anos, $98 \%$ dos estrangeiros que estão classificados nesse tipo de situação (marítimos em embarcações de turismo estrangeiras) têm o Estado de São Paulo como destino (Tabela 1).

As principais origens dos estrangeiros com este tipo de autorização são Filipinas (26\%) e Índia (13\%), totalizando quase $40 \%$ das autorizações para marítimos a bordo de embarcações de turismo estrangeira. Esse tipo de entrada é responsável pela configuração mais asiática do perfil dos trabalhadores autorizados a se inserirem no país (Tabela 1 ).

Os filipinos também representam o grupo com mais autorizações para profissionais, tripulantes e técnicos estrangeiros para trabalho a bordo de embarcação ou plataforma estrangeira sob contrato de prestação de serviços e de risco, com $19 \%$, seguidos pelos britânicos (13\%) e americanos (10\%). Com relação ao destino, este tipo de autorização diferencia-se completamente do anterior, já que $90 \%$ deles apresentam o Rio de Janeiro como local de destino e $2 \%$ o Estado de São Paulo. Esse panorama é compreensível, considerando-se que a possível explicação para isso está na relação desse tipo de embarcação ou plataforma com a expansão do Brasil na exploração do petróleo e do pré-sal. Com isso, o Rio de Janeiro, como uma das principais fontes de exploração de tais atividades, torna-se o local primordial de concentração desses estrangeiros. ${ }^{18}$

Ao se analisarem os vistos concedidos para transferência de tecnologia e/ou prestação de serviço de assistência técnica sem vínculo empregatício com relação à origem, observa-se uma concentração de autorizações para americanos (16\%), japoneses (10\%) e chineses (9\%). Ou seja, um perfil de países altamente industrializados. Quanto ao local de destino, observa-se que Rio de Janeiro (39\%), São Paulo (38\%), Minas Gerais (7\%) e Amazonas (7\%) são os estados de maior concentração dos estrangeiros com tais concessões de visto, uma vez que os três primeiros são os de maior desenvolvimento industrial e tecnológico do país e o último apresenta uma política permanente de atração industrial. ${ }^{19}$

\footnotetext{
${ }_{18}$ Ao operarem em águas jurisdicionais brasileira, de acordo com o tempo e a atividade, empresas afretadoras ou contratantes deverão admitir profissionais brasileiros para trabalhar a bordo das embarcações e plataformas afretadas ou contratadas, de acordo com especificações da alteração feita na RN58/2003. 0 percentual de brasileiros a serem contratados pode variar de 1/5 até 2/3 (http://portal.mte.gov.br/data/files/FF8080812B21345B012B2BFC0C885CBD/ ata_20060720_05.pdf).

${ }^{19}$ Zona Franca de Manaus.
} 


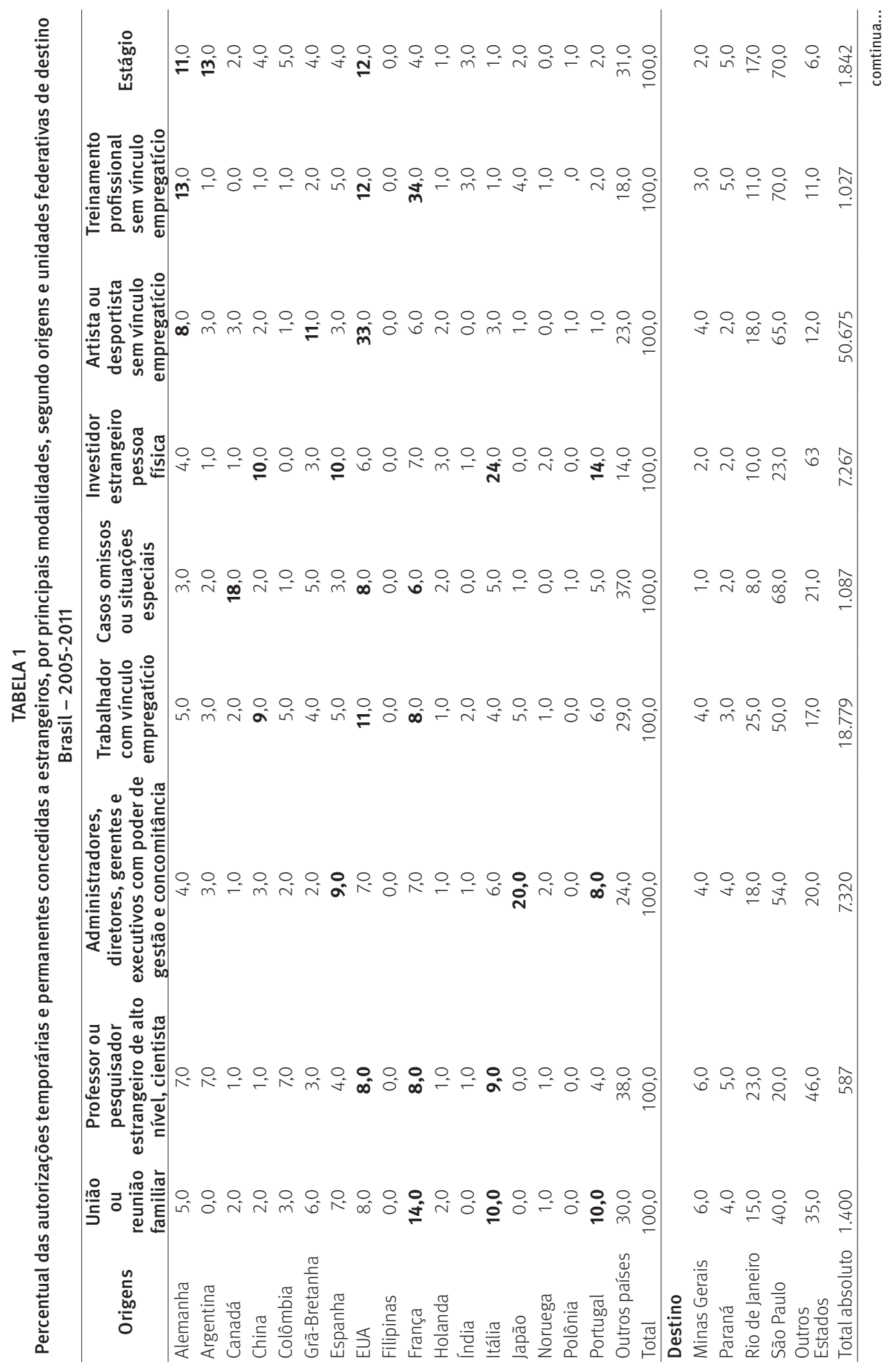




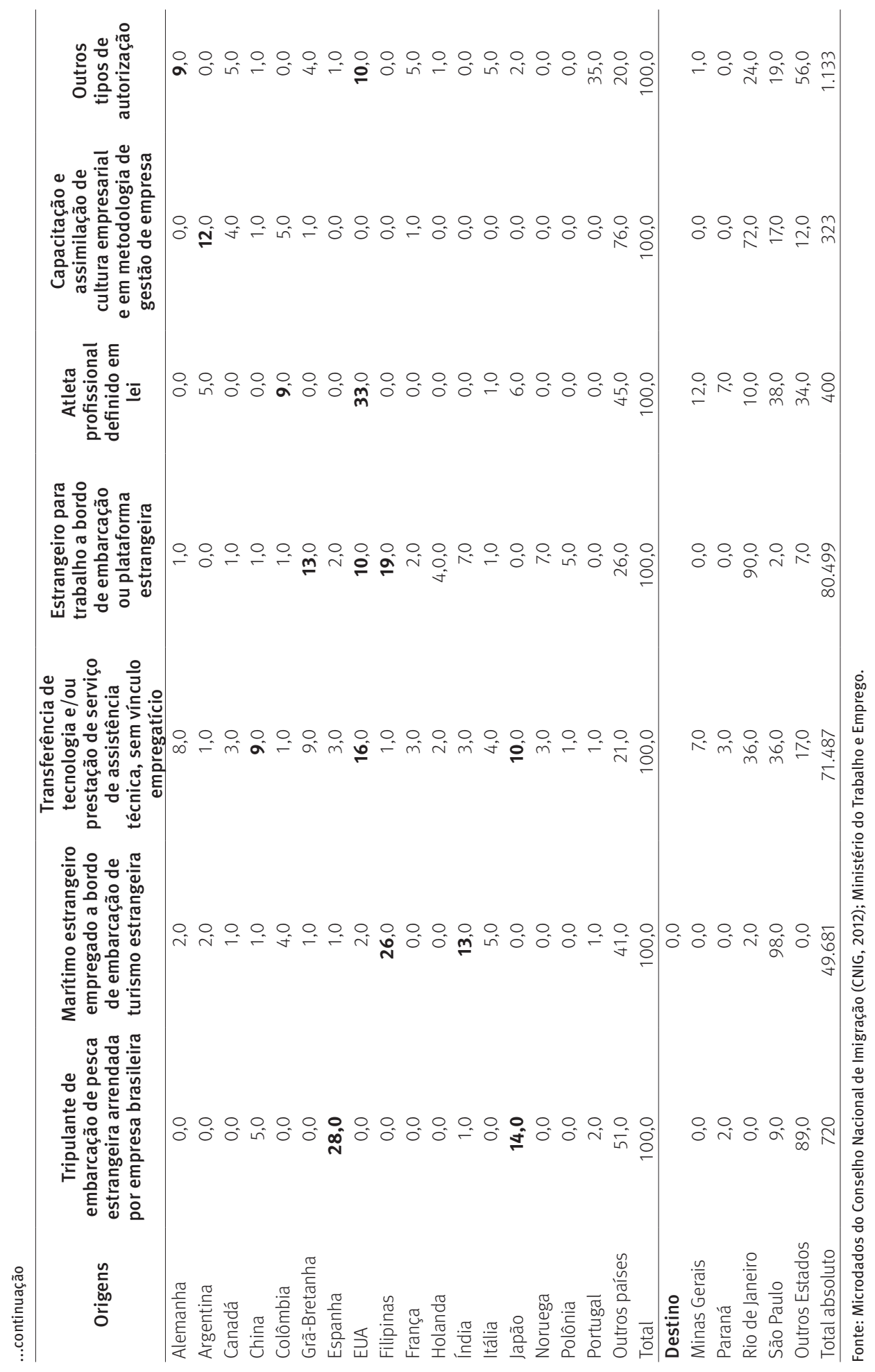


Diferentemente, o investidor pessoa física já engloba indivíduos originários majoritariamente do sul da Europa (24\% de italianos, 14\% de portugueses, $10 \%$ de espanhóis e $10 \%$ de chineses), com uma distribuição espacial diferente no território brasileiro. Os estados do Ceará (18,5\%), Rio Grande do Norte (15,7\%) e Bahia (12\%) são os de maior importância, só perdendo para São Paulo (23\%). Em seguida, vem Rio de Janeiro e Santa Catarina como destinos desses investidores, acompanhados por Minas Gerais e Paraná. Esse resultado mostra a relevância de se estudar esses estrangeiros na Região Nordeste, uma vez que, até onde é de nosso conhecimento, não há estudos sobre os mesmos, como exposto por Fernandes, Castro e Knup (2012).

Para as concessões de vistos para trabalhadores com vínculo empregatício em seus locais de origem, os principais países são EUA (11\%), China (9\%) e França (8\%). Para administradores, diretores, gerentes e executivos com poderes de gestão, os países de origem são Japão (20\%), Espanha (9\%), Portugal (8\%) e Alemanha (4\%). 0 mesmo se verifica com as autorizações para artistas e desportistas, originados principalmente dos EUA (33\%), Grã-Bretanha (11\%) e Alemanha (8\%). A situação de reunificação familiar encontra-se, principalmente, entre franceses (14\%), italianos (10\%) e portugueses (10\%). Quanto aos destinos desses estrangeiros com tais vistos concedidos, São Paulo e Rio de Janeiro são os mais comuns.

Um ponto a destacar é o caso dos indivíduos que entram como vítima de tráfico de pessoas ou refugiados no país ou por razões humanitárias (724 casos para todos os anos). ${ }^{20}$ Como exposto por Baeninger e Peres (2011), esses estrangeiros são haitianos, principalmente, e pessoas oriundas dos países africanos que se encontram nessa categoria no país. Dos dados cumulativos analisados, $98,5 \%$ correspondem a haitianos e os outros 1,5\% distribuem-se entre os originários da Nigéria, Angola, Nova Guiné, República do Congo, Peru e Bolívia. 0 ano de grande concessão de tais vistos é 2011, concentrando 717 do total de 724 autorizações entre 2005 e 2011, sendo todos para haitianos com visto por razões humanitárias. ${ }^{21}$

Por fim, ressalta-se que são os estrangeiros oriundos de países desenvolvidos, principalmente EUA, França, Espanha, Grã-Bretanha, Japão e Itália, que têm o maior número de entradas em situações de vistos de melhor inserção no mercado de trabalho, tais como diretores e gerentes de empresas; professores, pesquisadores e cientistas; investidores; artistas, desportistas ou atletas profissionais; trabalhadores com vínculo empregatício; e transferência de tecnologia e/ou assistência técnica. Esses dados podem indicar uma possível seletividade quanto à origem, no que se refere a países desenvolvidos e em des-

\footnotetext{
${ }^{20}$ Esses encontram-se na categoria "outros tipos de autorizações".

${ }^{21}$ Os haitianos não se encaixam no perfil de refugiados, pois recebem um visto humanitário com permanência de cinco anos no Brasil, por meio da Resolução Normativa n. 97/2012. A resolução teria vigência de dois anos e o número de vistos era restrito a 1.200 por ano, não incluídos aqueles referentes à reunificação familiar. Pela Resolução Normativa n. 102/2013, o Brasil retirou a limitação de concessão a 1.200 vistos anuais e, em outubro de 2013, prorrogou por mais um ano a RN 97, que expiraria em janeiro de 2014 (BRASIL, 2014).
} 
envolvimento, no entanto, esta análise somente pode ser realizada considerando todas as solicitações remetidas aos ministérios e seus desfechos.

\section{Considerações finais}

Este trabalho teve como objetivo apresentar uma análise do perfil e da situação dos estrangeiros autorizados a se estabelecerem no Brasil, entre 2005 e 2011. Inicialmente, retratou-se a história das políticas migratórias brasileiras, uma vez que o Brasil nunca deixou de ser um país de absorção de imigrantes, ainda que em escalas distintas. A política migratória definiu-se por um caráter mais restritivo e seletivo com o Estatuto do Estrangeiro de 1980 , pois o interesse nacional sempre foi tido como o princípio norteador para a formulação das políticas migratórias nacionais, sobrepondo-se a tratados internacionais e aos direitos humanos dos imigrantes. De todo modo, as demandas trazidas pelas mudanças, que ocorriam no processo migratório brasileiro, levaram a ajustes que acompanhassem estas mudanças e demandas por meio do CNIg. Mas essas ainda parecem ser insatisfatórias.

O número de autorizações de entrada no país para trabalho, reunificação familiar, ajuda humanitária e outras cresceu sistematicamente ao longo dos anos analisados. Isso pode se dever, em parte, à atração do país em função do novo contexto econômico e dos processos de anistia realizados pelo Estado de forma a regularizar a situação dos trabalhadores imigrantes no país, além de ser o resultado de um melhor ajuste da lei com relação aos tipos de solicitação por parte dos imigrantes e aos tipos de demandas no mercado brasileiro. Essas autorizações são, mais frequentemente, para norte-americanos, asiáticos e europeus. As outras origens vêm sofrendo queda ou mantendo-se estáveis em baixos níveis.

Identificou-se que o destino desses estrangeiros, no período como um todo, se concentra, fundamentalmente, na Região Sudeste, principalmente nos estados do Rio de Janeiro e de São Paulo. Contudo, é possível perceber um crescimento na dispersão destes imigrantes para outros estados no país, principalmente dos europeus no Nordeste, os quais merecem um estudo à parte, quando os dados são observados anualmente. Verificou-se que a maioria recebe autorização para residência temporária no país. Com relação ao perfil sociodemográfico, observa-se que os estrangeiros autorizados em todo período analisado são, em sua maioria, homens, o que chama a atenção para estudos futuros, já que vai contra a teoria da feminização da imigração no mundo. 0 perfil etário do grupo é adulto, com a média de idade em 38,24 anos. 0 nível educacional dos estrangeiros é alto.

A situação dos estrangeiros no país pode ser definida pelos tipos de autorização concedidos a eles. Sobressaem as autorizações para marítimos a bordo de embarcação estrangeira, transferência de tecnologia/prestação de assistência técnica sem vínculo empregatício, artista ou desportista sem vínculo empregatício, empregado com contrato de trabalho, administrador/diretor/gerente/executivo, investidor estrangeiro/pessoa física e visto para estágio. Essas autorizações sinalizam uma busca pela atração de recursos financeiros e expertise para o país, visto que estão vinculadas à presença e atuação de uma mão de obra especializada. 
Essas autorizações consideradas mais estratégicas pelo Brasil recebem trabalhadores oriundos das regiões mais desenvolvidas (Europa e América do Norte, principalmente), enquanto as demais são para trabalhadores oriundos de regiões menos desenvolvidas (o caso dos filipinos, indianos e latinos) e que apresentam um nível educacional inferior quando comparado ao primeiro grupo.

Ressalta-se que, embora tenha aumentado o número de autorizações concedidas no período, alguns grupos de estrangeiros ainda têm dificuldade de obter tais autorizações, como nos casos de bolivianos e outros grupos de países em desenvolvimento e de pessoas com baixa qualificação. Isso sugere uma restrição e seletividade na concessão de autorizações de estadia no país. Pode-se inferir, também, sobre uma possível seletividade quanto ao sexo e nível educacional desses autorizados .

Contudo, destaca-se que são inferências e não confirmações, pois não foi testada a hipótese de seletividade, já que não há informações sobre aqueles candidatos que não obtiveram autorização para estadia no país. Da mesma forma, a partir dos dados analisados não é possível identificar quem poderia ser seletivo: o governo brasileiro; o mercado de trabalho (de origem e/ou de destino); ou uma seletividade na própria solicitação dos estrangeiros. Entretanto, a política migratória brasileira acaba por assegurar uma seletividade nas autorizações de permanência concedidas, pois, como exposto por Póvoa Neto (2010, p. 491), “encontra-se internacionalmente reconhecido, a estes [Estados nacionais], o poder soberano sobre o controle de ingresso de estrangeiros, assim como sobre os limites de seu acesso ao mercado de trabalho".

\section{Referências}

ARAÚJO, J. R. D. C. Imigração e futebol - O caso do Palestra Itália. São Paulo: Sumaré, 2000. Disponivel em: 〈http://www.livrariacultura.com.br/scripts/cultura/resenha/resenha.asp?isbn $=8585408316 \&$ sid $=15824117312718453172148867$ . Acesso em: out. 2011.

ASSIS, G. D. O.; SASAKI, E. M. Os novos migrantes do e para o Brasil: um balanço da produção bibliográfica. In: CASTRO, M. G. (Ed.). Migrações internacionais - contribuições para políticas. Brasília: CNPD, 2001, p.615-669.

AZEVEDO, C. M. M. D. Dois estudos sobre imigração e racismo. São Paulo: Anna Blume, 2012.

BAENINGER, R. Estrangeiros autorizados a trabalhar no Brasil. In: CGEE (Ed.). Doutores 2010: estudos da demografia da base técnico-científica brasileira. Brasília: Centro de Gestão e Estudos Estratégicos, 2010, cap. 5, p.443-508.

Imigração boliviana no Brasil. Campinas: Núcleo de Estudos de População - Nepo/ Unicamp; Fapesp; CNPq; Unfpa 2012.

BAENINGER, R.; PERES, R. G. Refugiados africanos em São Paulo, Brasil: espaços da migração. Revista Internacional em Língua Portuguesa, v. III, n. 24, p. 97-110, 2011.

BAENINGER, R. A.; PATARRA, N. L. Mobilidade espacial da população no Mercosul: metrópoles e fronteira. Revista Brasileira de Ciências Sociais, v. 21, n. 60, p. 83-102, 2006. Disponível em: 〈http://www.scielo.br/scielo.php?pid=S0102-69092006000100005\&script=sci_arttext〉. Acesso em: out. 2011. 
BARRETO, L. P. T. F. Considerações sobre a imigração no Brasil contemporâneo. In: CNPD (Ed.). Migrações internacionais: contribuições para políticas. Brasília: Cidade, 2001.

. A política de refúgio no Brasil contemporâneo. In: BOUCAULT, C. E. D. A.; MALATIAN, T. O. (Ed.). Políticas migratórias: fronteiras dos direitos humanos no século XXI. Rio de Janeiro: Renovar, 2003, p.199-208.

BONASSI, M. Canta, América sem fronteiras! Imigrantes latino-americanos no Brasil. São Paulo: Loyola, 2000.

BRASIL. Câmara dos Deputados. Projeto de Lei (PL) 5655/2009 - Dispõe sobre o ingresso, permanência e saída de estrangeiros no território nacional. Brasília, 2009. Disponível em: 〈http:// www.camara.gov.br/proposicoesWeb/prop_mostrarintegrà. Acesso em: jan. 2013.

Conselho Nacional de Imigração. Resolução Normativa n. 97, de 12 de janeiro de 2012 - Dispõe sobre a concessão do visto permanente previsto no art. 16 da Lei no 6.815 , de 19 de agosto de 1980, a nacionais do Haiti. Brasília, 2012. Disponível em: 〈http://portal.mte. gov.br/data/files/8A7C816A350AC8820135687F345B412D/RESOLU\%C3\%87\%C3\%830\%20 NORMATIVA\%20N\%C2\%BA\%2097.pdf〉. Acesso em: out. 2011.

Ministério do Trabalho. Perfil migratório do Brasil 2009. Brasília: Ministério do Trabalho e Emprego (MTE) e Organização Internacional para as Migrações (OIM), 2010. Disponível em: 〈http://portal.mte.gov.br/data/files/FF8080812CB90335012CBD3E35CB6605/ perfil_migratorio_2009.pdf〉.Acesso em: out. 2011.

Presidência da República. Decreto n. 86.715 de 10 de dezembro de 1981. Brasília, 1981a.

Lei n. 6.815 de 19 de agosto de 1980 - Define a situação jurídica do estrangeiro no Brasil, cria o Conselho Nacional de Imigração. Brasília, 1981b. Disponível em: 〈http://www. planalto.gov.br/ccivil_03/Leis/L6815.htm>. Acesso em: jan. 2013.

Lei n. 6.964 de 9 de dezembro de 1981 - Altera disposição da Lei n. 6815, de 19 de agosto de 1980, que define a situação jurídica do estrangeiro no Brasil, cria o Conselho Nacional de Imigração, e dá outras providências. Brasília, 1981c. Disponível em: 〈http://www.planalto. gov.br/ccivil_03/leis/L6964.htm〉. Acesso em: out. 2011.

BRITO, F. Ensaio sobre as migrações internacionais no desenvolvimento do capitalismo. Revista Brasileira de Estudos de População, v. 12, n. 1/2, p. 21-33, 1995.

CAPES. Banco de tese Capes. Brasília, 2010. Disponível em: «http://www.capes.gov.br/servicos/ banco-de-teses〉.

CARNEIRO, M. L. T. Cumplicidade secreta: o Brasil diante da questão dos refugiados judeus (1933-1948). In: BOUCAULT, C. E. D. A.; MALATIAN, T. O. (Eds.). Políticas migratórias: fronteiras dos direitos humanos no século XXI. Rio de Janeiro: Renovar, 2003, p. 257-275.

CASTELS, S.; MILLER, M. J. The age of migration international population movements on the modern world. Hong Kong: Macmillan, 1993.

CAVALCANTI, L.; OLIVEIRA, A. T.; TONHATI, T. (Orgs.). A inserção dos imigrantes no mercado de trabalho brasileiro. Brasília: Cadernos do Observatório das Migrações Internacionais, 2014.

CHISWICK, B. R. Are immigrants favorably self-selected? The American Economic Review, v. 89, n. 2, p. 181-185, 1999. Disponivel em: 〈http://www.jstor.org/pss/117103 〉. Acesso em: out. 2011.

CNIG - Conselho Nacional de Imigração. Base de dados de autorização de vistos a estrangeiros no Brasil de 2005 a 2011. Brasília, 2012.

COLLINS, R. The credential society: an historical sociology of education and stratification. New York: John Wiley, 1979. 
FAUSTO, B. Fazer a América: a imigração em massa para a América. 2. ed. São Paulo: Edusp, 2000. FERNANDES, D. M.; CASTRO, M. D. C. G. D.; KNUP, S. P. Fluxo de mão de obra da Europa para o Brasil. Economia, parlamentos, desenvolvimento e migrações: as novas dinâmicas bilaterais entre Brasil e Europa. Rio de Janeiro: Konrad-Adenauer-Stiftung, 2012, p. 135-150.

FIGOLI, L.; VILELA, E. M. Migración, identidade y multiculturalismo: sirios y libaneses in Brasil. Papeles de Trabajo, v. 11, p. 27-43, 2003.

FGV - Fundação Getúlio Vargas. Cruzeiros marítimos: estudo de perfil e impactos econômicos no Brasil. Rio de Janeiro, 2012.

KEHDY, M. O. A presença japonesa em Minas Gerais: imigração e investimento (1908-2008). Belo Horizonte: Associação Mineira de Cultura Nipo-Brasileira, 2010.

MARTES, A. C. B. Velho tema, novos desafios - gestão pública da imigração. Cadernos Adenauer, v. X, n. 1, p. 9-27, 2009.

MASSEY, D. S. et al. Theories of international migration: a review and appraisal. Population and Development Review, v. 19, n. 3, p. 431-466, 1993.

MELO, H. P. D.; ARAÚJO, J. L. D.; MARQUES, T. C. D. N. Raça e nacionalidade no mercado de trabalho carioca na Primeira República: o caso da cervejaria Brahma. Revista Brasileira de Economia, v. 57, n. 3, p. 535-569, 2003. Disponivel em: 〈http://www.scielo.br/scielo.php?script=sci_artte xt\&pid=S0034-71402003000300003〉.

MILESI, R. Regularização de imigrantes no Brasil, pelo sistema do registro provisório - Anistias de 1981, 1988 e 1998. Brasília: Instituto Migrações e Direitos Humanos - Rede Solidária para Migrantes e Refugiados, 2009. Disponível em: «www.migrante.org.br/anistias_no_brasil_artigo_ rosita_05jun09.doc>. Acesso em: nov. 2011.

MONSMA, K. Vantagens de imigrantes e desvantagens de negros: emprego, propriedade, estrutura familiar e alfabetização depois da abolição no oeste paulista. Dados - Revista de Ciências Sociais, v. 53, n. 3, p. 509-543, 2010. Disponivel em: 〈http://www.scielo.br/pdf/dados/ v53n3/a01v53n3.pdf>. Acesso em: nov. 2011.

MOULIN, C. Os direitos humanos dos humanos sem direitos: refugiados e a política do protesto. Revista Brasileira de Ciências Sociais, v. 26, n. 76, junho 2011. Disponivel em: 〈http://www.scielo. br/scielo.php?script=sci_arttext\&pid=S0102-69092011000200008〉. Acesso em: jan. 2015.

PATARRA, N. L. Migrações internacionais de e para o Brasil contemporâneo: volumes, fluxos, significados e políticas. São Paulo em Perspectiva, v. 19, n. 3, p. 23-33, 2005. Disponível em: 〈http://www.scielo.br/pdf/spp/v19n3/v19n3a02.pdf〉. Acesso em: nov. 2011.

Migrações internacionais: herança XX, agenda XXI. Campinas: FNUAP, 1996.

PATARRA, N. L.; FERNANDES, D. Brasil: país de imigração? Revista Internacional em Língua Portuguesa - Migrações, v. III, n. 24, p. 65-96, 2011.

PERES, R. G. A imigração de bolivianas na fronteira: desafios teórico-metodológicos. In: BAENINGER, R. (Ed.). Imigração boliviana no Brasil. Campinas: Nepo, Fapesp, CNPq, Unfpa, 2012, p.271-295.

PIORE, M. J. Birds of passage: migrant labor and industrial societies. Cambridge: Cambridge University Press, 1979.

PORTES, A. The economic Sociology of immigration: essays on networks, ethnicity, and entrepreneurship. New York: Russell Sage Foundation, 1995.

PÓVOA NETO, H.; SPRANDEL, M. Os objetivos da Conferência Internacional sobre População e Desenvolvimento (Cairo, 1994) e a política migratória brasileira. Brasil, 15 anos após a conferência 
do Cairo. Campinas: Associação Brasileira de Estudos Populacionais - Abep e UNFPA, 2009, p. 303-326.

PÓVOA NETO, H. Barreiras físicas como dispositivos de política migratória na atualidade. In: FERREIRA, F. P. et al. (Orgs.). A experiência migrante: entre deslocamentos e reconstruções. Rio de Janeiro: Garamond, 2010.

REIS, R. R. Soberania, direitos humanos e migrações internacionais. Revista Brasileira de Ciências Sociais, v. 19, n. 55, 2004.

SAKURAI, C. Imigração japonesa para o Brasil. Um exemplo de imigração tutelada - 1908-1941. In: XXII ENCONTRO NACIONAL DA ANPOCS. Anais... Caxambu, 1998.

Imigração tutelada. Os japoneses no Brasil. 2000. 191p. Tese (Doutorado) Departamento de Ciências Sociais, Universidade Estadual de Campinas, Campinas, 2000.

SALA, G. A. Características demográficas e sócio-ocupacionais dos migrantes nascidos nos países do Cone Sul residentes no Brasil. 2005. 243p. Tese (Doutorado) - Departamento de Demografia, Universidade Federal de Minas Gerais, Belo Horizonte, 2005. Disponível em: 〈http:// www.cedeplar.ufmg.br/demografia/teses/2005/Gabriela_AdrianaãSala.pdf〉.

SALES, T. Imigrantes estrangeiros, imigrantes brasileiros: uma revisão bibliográfica e algumas anotações para pesquisa. Revista Brasileira de Estudos de População, v. 9, n. 1, p. 50-64, 1992. Disponivel em: 〈http://www.abep.nepo.unicamp.br/docs/rev_inf/vol9_n1_1992/vol9_ n1_1992_4artigo_50_64.pdf〉. Acesso em: nov. 2011.

SALES, T.; SALLES, M. D. R. R. R. Política migratória: América Latina, Brasil e brasileiros no exterior. São Paulo: Idesp, 2002.

SAYAD, A. A imigração: ou os paradoxos da alteridade. São Paulo: Universidade de São Paulo, 1998.

SEYFERTH, G. As associações recreativas nas regiões de colonização alemã no Sul do Brasil. Travessia, v. 34, p. 24-30, 1999.

. Assimilação dos imigrantes no Brasil: inconstâncias de um conceito problemático. Travessia, v. 36, p. 44-50, 2000.

. Estudo sobre a reelaboração e segmentação da identidade étnica. Cadernos CERU, v. 2, n. 13, p. 9-37, 2002.

SILVA, S. A da. Costurando sonhos. Trajetória de um grupo de imigrantes bolivianos em São Paulo. São Paulo: Paulinas, 1997.

Bolivianos. São Paulo: Companhia Editora Nacional, 2005.

. Hispano-americanos no Brasil: entre a cidadania sonhada e a concedida. In: CNPD. Migrações internacionais: contribuições para políticas. Brasília: CNPD, 2001, p.489-502.

. Imigrantes hispano-americanos em São Paulo: perfil e problemática. In: BOUCAULT, C. E. D. A.; MALATIAN, T. O. (Eds.). Políticas migratórias: fronteiras dos direitos humanos no século XXI. Rio de Janeiro: Renovar, 2003, p. 289-304.

Bolivianos em São Paulo: entre o sonho e a realidade. Estudos Avançados, v. 20, n. 57, 2006. Disponivel em: 〈http://www.scielo.br/scieloOrg/php/reference.php?pid=S010340142006000200012\&caller=www.scielo.br〈=en〉. Acesso em: nov. 2011.

SIQUEIRA, S. Sonhos, sucesso e frustrações na emigração de retorno Brasil/Estados Unidos. Belo Horizonte: Argvmentvm, 2009.

SOUCHAUD, S.; CARMO, R. L. D.; FUSCO, W. Mobilidade populacional e migração no Mercosul: a fronteira do Brasil com Bolívia e Paraguai. Teoria \& Pesquisa, v. XVI, n. 1, p. 39-60, 2007. 
Disponível em:〈http://hal.ird.fr/docs/00/22/15/02/PDF/23_Teoria_Pesquisa_2007.pdf〉.Acesso em: nov. 2011.

TRUZZI, O. Reformulações na política imigratória de Brasil e Argentina nos anos 1930: um enfoque comparativo. In: BOUCAULT, C. E. D. A.; MALATIAN, T. O. (Eds.). Políticas migratórias: fronteiras dos direitos humanos no século XXI. Rio de Janeiro: Renovar, 2003, p. 233-256.

VAINER, C. Deslocados, reassentados, clandestinos, exilados, refugiados, indocumentados: as novas categorias de uma sociologia dos deslocados compulsórios e das restrições migratórias. In: CASTRO, M. G. (Ed.). Migrações Internacionais: contribuições para políticas. Brasília: CNPD, 2001.

VILELA, E. M. Sírios e libaneses e o fenômeno étnico: os jogos de identidades. 2002. Dissertação (Mestrado) - Departamento de Sociologia e Antropologia, Universidade Federal de Minas Gerais, Belo Horizonte, 2002.

Sírios e libaneses: redes sociais, coesão e posição de status. Revista Brasileira de Ciências Sociais, v.26, n.76, pp. 157-176, 2011a. Disponível em: http://www.scielo.br/scielo. php?script=sci_arttext\&pid=S0102-69092011000200009\&lng=en\&nrm=iso.

Desigualdade e discriminação de imigrantes internacionais no mercado de trabalho brasileiro. Dados - Revista de Ciências Sociais, v. 54, n. 1, p. 89-129, 2011b.

VILELA. E. M.; LOPES, L. B. F. Balanço da produção acadêmica sobre migração internacional no Brasil. BIB, n. 72, p. 55-88, 2011. Disponível em: 〈http://portal.anpocs.org/portal/index. php?option=com_docman\&task=cat_view\&gid=1141\&ltemid=435〉. Acesso em: jun. 2013.

\section{Sobre as autoras}

Elaine Meire Vilela é doutora em Ciências Humanas (Sociologia e Ciência Política) pela Universidade Federal de Minas Gerais. Professora adjunta do Departamento de Sociologia e Antropologia da Universidade Federal de Minas Gerais - UFMG.

Daniela Portella Sampaio é doutoranda do Instituto de Relações Internacionais da Universidade de São Paulo - e mestre em Sociologia pela Universidade Federal de Minas Gerais - UFMG.

\section{Endereço para correspondência}

\section{Elaine Meire Vilela}

Av. Antônio Carlos 6.627, Campus - FAFICH Pampulha

31270-901 - Belo Horizonte-MG, Brasil.

\section{Daniela Portella Sampaio}

Av. Prof. Lucio Martins Rodrigues, s/n, travessas 4 e 5 - Cidade Universitária

05508-020 - São Paulo-SP, Brasil.

\section{Abstract}

A portray on foreigners authorized to come to Brazil, from 2005 to 2011

The main purpose of this article is to bring a descriptive analysis about foreigners who are authorized to stay in Brazil in a temporary or permanent term, from 2005 to 2011; and to highlight its relation to Brazilian migration policy. As such, we worked with microdata from Brazilian Migration General Coordination (CNIg), at the Work and Employ Ministry. Based on the presented bibliography, our aim is to identify the existence of a selectivity tendency regarding 
the authorization of foreigners who accomplish to come to Brazil. Although, we cannot test this selectivity fact, as the information regarding the migrant profile, who had his/her authorization declined, is not available; we can infer this point from the data collected. The results show that the majority of issued authorizations refers to professional workers and investors, men, highly skilled, from developed countries (in general Americans, Europeans and Asians), and towards Brazilian Southeast. This profile of authorized migrants could be partially explained by Brazilian migration policy which remains restrictive and selective. Although it is not possible to identify the source of this selectivity - whether the Brazilian government, the labor market (for origin and destination), or just the specificities of foreigners' requests - Brazilian migration policy ensures this selectivity, regardless of whom could be the agent of this action.

Keywords: Foreigners. Migration policy. Authorizations. Selectivity.

\section{Resumen}

Una mirada sobre los extranjeros autorizados a entraren en Brasil, entre 2005 y 2011

La propuesta dese artigo es presentar un análisis descriptivo de los extranjeros autorizados a establecerse de manera temporaria o permanente en Brasil, por el período de 2005 a 2011, y su relación con la política de migración brasileña. Para eso, utilizamos los microdatos de la Coordinación General de la Migración (CNIg), del Ministerio del Trabajo y Empleo. Considerando la literatura presentada, nuestro intento es identificar si hay una tendencia a la selectividad de los extranjeros que entran en el país. Aunque no podamos testar tal facto, una vez que no tenemos las informaciones sobre los perfiles de los candidatos que tuvieron sus solicitudes negadas, es posible inferir tal cuestión por los datos analizados. Los resultados enseñan que los tipos de autorización concedidos son, en su mayoría, para trabajadores profesionales y inversores, hombres altamente cualificados, de países, en general, desarrollados (estadounidenses, europeos y asiáticos), y con destino al Sudeste del país. Este perfil de autorizados puede ser explicado, en parte, por la política de migración brasileña que continua a ser restrictiva y selectiva. Aunque no se pueda identificar la fuente de la selectividad - si el gobierno brasileño, el mercado de trabajo (origen y / o destino), o las propias solicitudes de los extranjeros - la política de inmigración brasileña asegura tal selectividad independientemente de quién sea el agente de esta acción.

Palabras clave: Extranjeros. Política de migración. Autorizaciones. Selectividad.

Recebido para publicação em 13/11/2013

Aceito para publicação em 24/05/2015 